\title{
Electrical conductivity structure along a few transects over the Indian Lithospheric domains
}

\author{
CSIR-National Geophysical Research Institute, Hyderabad, India.Email: patrobpk@ngri.res.in
}

(Received : 30/09/2019; Revised accepted : 13/10/2019)

https://doi.org/10.18814/epiiugs/2020/020042

This paper presents a brief review of the electrical signatures of the subsurface structure of the Indian lithosphere along a few transacts across some of the important geological provinces using modelling results from magnetotelluric (MT) studies. The case studies discussed here includes the Himalayan collision zone, Deccan Volcanic Province, Narmada-son Lineament zone, Dharwar and East India Cratons, Southern Granulite Terrain (SGT). The subsurface electrical models discussed are mostly from broad band and long period MT studies, providing deeper structural information. In the Himalayas, the thrust system, mainly the Main Central Thrust and Indus Tsangpo Suture Zone are reflected as low resistive zones. Several hidden basement fractures/faults are identified in the Deccan Volcanic Province, some of which might have facilitated magma spreading vertically as well as horizontally. The MT models provided a broad view of the plumbing geometry of the Deccan volcanics. An Archean suture zone has been identified in the western Dharwar carton. Electric Moho has been delineated in the Eastern Indian Craton suggesting absence of conducting continental lower crust in this region. MT models in the Kutch region imaged a fluidized zone to which the observed seismicity in the region is shown to be confined. In the south, the Achankovil Shear Zone (ACSZ) in the SGT is reflected as a well-defined north dipping conductive structure, which might have played a significant role in the subduction-collision tectonic processes of the region. Largescale 3D cooperative modelling studies coupled with seismological and gravity models is the key approach to derive a geologically meaningful model of the lithospheric structure, a way forward.

\section{Introduction}

The tectonic evolutionary history of the Earth’s interior generally gets reflected in the nature of signatures like enrichment or depletion phenomena of the lithospheric mantle. For example, dewatering of the subduction slab leads to release of fluids and induced melt enriches the overlying mantle. Similarly, the rifting events lead to partial melting and the possible mixing of fertile elements with the melt gives rise to a depleted lithosphere. Such signatures, in the absence of any high temperature/melt events during the subsequent period, can remain unaltered in the lithosphere for hundreds of millions of years. Detection and mapping of such signatures would be of great help in understanding the tectonic evolution of the lithospheric composition and structure in any region of investigation. In this connection, amongst the several geophysical methods that could be deployed for such investigation, the Magnetotellurics (MT) is known to be highly effective in probing and evaluating the lithospheric structure and inhomogeneities. This is because, (MT) being a passive electromagnetic method that images the physical property of electrical conductivity and is capable of penetrating to deeper levels covering the entire lithosphere. Further, MT is highly sensitive even to minor changes in the interconnected conducting mineralogy and fluids, and thus is ideal for distinguishing the lithospheric segments of different degrees of enrichment as well as depletion. Additionally, the sensitivity to these minor phases means that fossil fluid pathways associated with the ascent of mineralising fluids and metals are also readily detectable with MT.

Indian geology is quite complex with a wide range of tectonics and structural scenario, including the vast cover of basalt, the Deccan traps, occupying most parts of western India, the complex thrust regions of north and northeast Himalayan terrains with collision tectonics, a mosaic of cratons in peninsular India and a number of large sedimentary basins. During the last few decades MT studies have been carried out over different segments of the Indian continent and this has facilitated to get some understanding of the nature and structure of the Indian lithosphere. It is true that present review is intended at imaging the deep crustal and mantle structure to constrain tectonic evolution of Indian subcontinent. These studies as an off shoot bring out the potential showing the scope and prospective of the MT studies in hydrocarbon, geothermal exploration, resource location, seismogenesis etc. Some details of these applied studies can be found in the research publications (Sarma et al., 1983; Gupta et al., 1996; Bhattacharya et al., 2003; Sarma et al., 2004; Harinarayana et al., 2006a; Satpal et al., 2006; Pandey et al., 2009; Sinharay et al., 2010; Rawat et al., 2014; Patro et al., 2015; Sircar et al., 2015; Arora et al., 2017; Mohan et al., 2017; Patro, 2017). Therefore, case studies 
presented here are carefully selected to highlight the allied applications.

\section{MT studies in the Deccan Trap region}

The Deccan volcanic province (DVP) located in the northern part of the Dharwar craton of the peninsular shield (Figure 1) is one of the world's biggest Large Igneous Province (LIPs) (Olsen, 1999) and has received a wide attention. However, its genesis and evolution are still poorly understood. The DVP has a total exposed area of about half a million square kilometres, lying between latitudes $16-24^{\circ} \mathrm{N}$ and longitudes $70-$ $77^{\circ} \mathrm{E}$ mainly occupying the western, north-western and central Indian peninsula (Figure 1). It is postulated that an equivalent area of the Deccan Traps has been down faulted along the western coastal region and the volume of erupted material could have been well over a million $\mathrm{km}^{3}$. The approximate volume of the lavas poured out is estimated to be about $2 \times 10^{6} \mathrm{~km}^{3}$. Geochronological studies $\left({ }^{40} \mathrm{Ar} /{ }^{39} \mathrm{Ar}\right)$ suggest the timing of eruption to be $65 \pm 0.9$ million years (e.g., Hofmann et al., 2000) and 66-67.4 \pm 0.9 Ma (Pande et al., 2004).

Mapping the subtrappean lithology in the Deccan Volcanic Province has been a challenging task for several decades. Application of MT in Deccan Trap (Saurashtra) region, provided the answer for this long awaited solution to the problem of detection of subtrappean sediments and also provided valuable insights into the nature of subtrappean lithology at deeper levels as well. The geological models from paleo river channel study in the Saurashtra region suggested gradual thickening of sediments towards south. Later, the MT studies brought out the presence of a thin sediments towards south and thick sediments towards northwestern part of the Saurashtra. Subsequently the deep drilling (3.5 km) carried out at Lodhika which validated the findings from MT studies (Harinarayana, 2008; Patro, 2017).

The two-dimensional MT model obtained along the Sangole Partur traverse in the DVP region (Figure 2) i.e in the northern part of Dharwar craton brought out a high resistive ( 10,000 ohm-m) crustal column for a major part of the profile, interspersed by a few conductors that extend from upper to lower crustal levels. Based on the electrical resistivity character and the shape and depth range of the conductors these crustal conductors are inferred to be due to fluid enriched channels/fracture zones traversing across crustal segments. Further, an upper mantle high conductive feature of limited areal extent is also observed in one of the profiles. Considering the electrical resistivity character at the crustal and upper mantle depths, and the geothermal conditions in the region (average surface heat flow value is around $37 \mathrm{~mW} / \mathrm{m}^{2}$ ) a cool lithospheric/shield segment in this region is inferred. The lithospheric column in this region deduced from MT basically shows a two layered structure with a very high resistive (several thousand ohm-m) segment top layer and moderately resistive (a few hundred ohm-m) second layer.

The geophysical studies including Deep Seismic Sounding (DSS) investigations and MT studies in the DVP close to Western Ghats provided evidence for a normal granite-gneissic crustal column underneath the basalt cover. DSS studies across the west coast of India shows a thinning of crust from west to east (Kaila et al.,1981). The crustal thickness at the west coast near Koyna is reported to be around $30 \mathrm{~km}$ as against the normal crustal thickness of $38 \mathrm{~km}$ in the 
Deccan plateau towards east. DSS studies suggest a significant crustal thinning $(22 \mathrm{~km})$ at the west coast near Surat (Kaila, 1988). This thinning of the crust, pointing out to possible crustal underplating, is interpreted as a Moho upwrap which might have acted as a source for Deccan volcanism (Kaila, 1988). But, results from MT as well as Receiver function studies do not support such a possibility. Receiver function analysis suggest a normal crustal thickness typically of shield (36 - $41 \mathrm{~km}$ ) at the western margin of the DVP near Mumbai (Mohan and Kumar, 2004) and thus do not support for magmatic under platting in this region. The electrical subsurface model derived from MT studies in this region also shows the crustal column as highly resistive indicating a normal shield region (Sarma et al., 2004; Patro et al., 2005; Patro and Sarma, 2009) and is consistent with the results of receiver function analysis.

MT models in the DVP region show (Figure 2) high resistivity values for the lithospheric upper mantle depths up to about $120 \mathrm{~km}$. These values fall within the range of the two theoretical conductivitydepth profiles (Artemieva, 2006) corresponding to the two typical surface heat flow values of 37 and 50 $\mathrm{mW} / \mathrm{m}^{2}$. The lithospheric thickness map of the peninsular India on the basis of heat flow data shows a decrease in thickness of the lithosphere from south to north in the Dharwar craton with a maximum value of $185 \mathrm{~km}$ in the central region (Negi et al., 1986). MT models from the DVP brought out a High Resistive Lithospheric Layer (HRL), the thickness of this layer decreases from south to north (Patro and Sarma, 2009).

High resistivities observed in the MT models in the cratonic lithospheric mantle regions are inferred to be the result from olivine-orthopyroxine-clinopyroxinne dominated mineralogy at temperatures ranging from a few hundred to a thousand degree celcius (Jones et al., 2003). For subcontinental upper mantle the Average Continental Garnet Iherzolite model (ACGL) is known to represent the cratonic regions more closely (Jordan, 1979) compared to the Pyrolite model (Irifune and Ringwood, 1987). The decrease in resistive components like clinopyroxene or increase in conductive components like orthopyroxene and olivine in the mantle matrix may contribute to the variations in the bulk conductivities of mantle material depending on the depth and temperature. Higher conductivities in the lower layer of the upper mantle as observed in the MT models is in agreement with such compositional changes associated with the depleted conditions in the Dharwar craton. Another important feature detected in DVP is the presence of a major upper mantle-high conductive feature at a depth of around $80 \mathrm{~km}$ which extends over a length of $120 \mathrm{~km}$ (see Figure 2). This mantle conductor could be related to the postulated subduction of western Dharwar craton underneath the Eastern Dharwar craton (Patro and Sarma, 2009).

Saurashtra and Kutch regions forms the western part of the DVP. The Saurashtra region is bounded by the Cambay rift basin to the east, Narmada rift basin in the south and Kutch rift basin to the north. This region has been uplifted due to different stages of rifting, reactivation of fault zones and Deccan Volcanism. Broad band and Long period magnetotellric (LMT) study was carried out in the northern part of the Saurashtra (Kumar et al., 2018). The two dimensional geo-electric model (Figure 3) delineated the electrical signature of the Jamnagar, Jasdan and western part of Cambay basins. For the location of the profile see (5) in Figure 1. A significant conductive anomaly is delineated (A) beneath Cambay basin, which is close to the plume outburst region of the Reunion hotspot. This anomaly is interpreted as interconnected melts that have been fed to crustal layers by asthenospheric upwelling (Kumar et al., 2018).

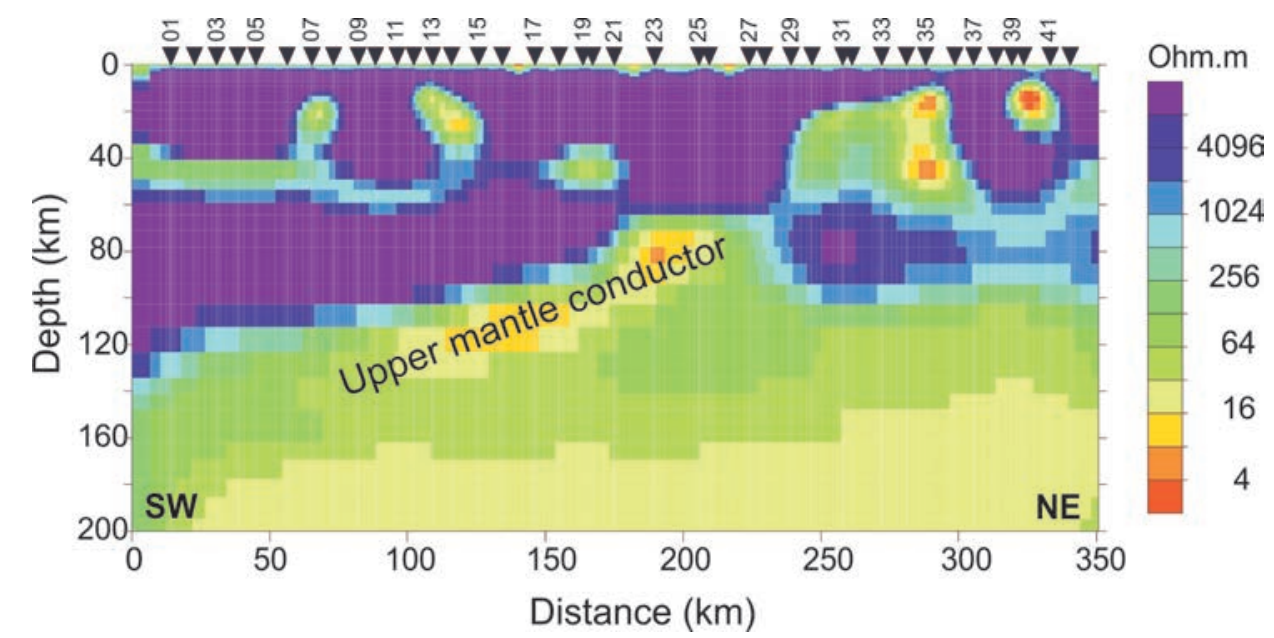

Figure 2. Deep geoelectric section along a profile (Sangole (SW) to Partur (NE)) on the Deccan Volcanic Province (Patro and Sarma, 2009). For the profile direction, see 10 in Figure 1.

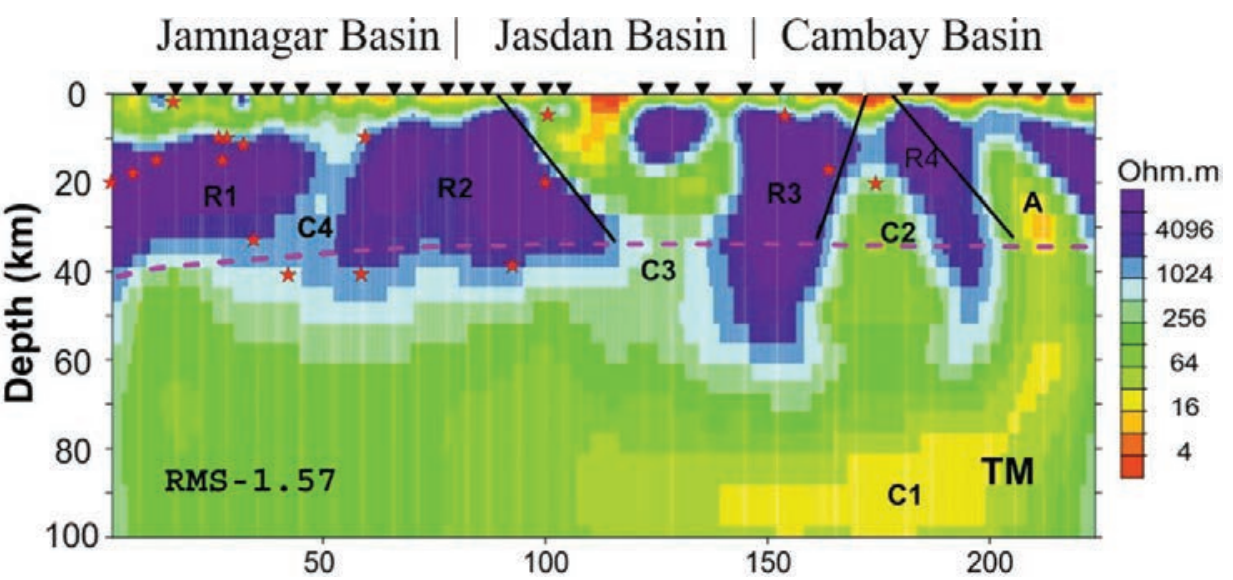

Figure 3. Two dimensional resistivity model (Kumar et al., 2018) obtained from the inversion of transverse magnetic (TM) mode data (see 5 in Figure 1 for profile location). It may be seen that the Jamnagar basin is underlain by high resistive layers ( $R 1$ and $R 2)$ with a moderately conductive zone C4. The resistive unit R4 forms the western flank of the Cambay basin. Moho is plotted as dashed line, obtained from Chopra et al. (2014). It may be seen that the high resistive layer and Moho boundary is well correlated beneath Jamnagar and Jasdan basin. Red stars represent the microseismicity taken from ISC catalogue. 
Apart from delineating the electrical nature of the known faults in the Kutch basin, a new fault Jakhau-Mundra Fault was delineated from the regional MT studies carried out in the Kutch basin (Sastry et al., 2007). The genesis of earthquakes in the Kutch basin was studied using MT and local earthquake tomography studies (Kumar et al., 2017). The joint interpretation of MT derived 2D electrical image and seismic tomography inferred the presence of a fluid reservoir at depths of $35-40 \mathrm{~km}$. From the figures 4 it may be seen that, the seismicity is confined mainly to middle to lower crustal depths. It coincides with the high conductive zone below the South Wagad Fault (see Figure 4). Kumar et al. (2017) interpret the SWF as a fluidized zone that extends downwards and gets connected to an upper mantle fluid reservoir and acts as a fluid channel.

\section{MT studies in Central India across the Narmada-son Lineament}

The Narmada-Son Lineament zone in Central India witnessed a complex tectonic history as suggested from various geological and geochronological studies. This includes two major tectonic episodes, 1. Mesozoic rifting and 2. Late Cretaceous Deccan Volcanic episode. In order to understand the subsurface structure and its relation to tectonics, several geophysical studies were carried out during the last few decades (Kaila et al., 1981, 1985, 1989; Shanker, 1991; Verma and Banerjee, 1992; Singh and Meissner, 1995). The two dimensional models derived from magnetotelluric studies delineated several major subsurface electrical conductors many of them associated with the known major fault/lineament features in the NSL region (Gokarn et al., 2001; Rao et al., 2004; Patro et al., 2005; Naganjaneyulu and Santosh, 2010; Abdul Azeez et al., 2013). These conductive features are attributed to fault zones filled with mafic material and/or fluids.
Three dimensional modelling of the MT data was carried out using data from 153 stations covering western most segment of NSL region (Patro and Sarma, 2016). The data was inverted at 8 periods ranging from 0.03 to $100 \mathrm{~s}$ using WSINV3DMT (Siripunvaraporn et al., 2005). The final model has brought out several crustal conductors with different geometrical configurations, distributed at different depth levels. Figure 5 shows the 3D MT model as vertical slices covering the entire block of the western most segment of the NSL. As may be seen from the different sections, the top layer $(2-3 \mathrm{~km})$ consists of moderately resistive (100-300 ohm-m) trap layer overlying a conductive sediment layer. The third one, high resistive layer represents granitic basement corresponding to the upper crustal layer which shows several linear conductive features representing fracture zones that extend upto $10-15 \mathrm{~km}$ depth. The lower crust is observed to be moderately resistive except at a few segments. A significant finding of this 3D modelling study is the delineation of several subsurface high conductive features with well-defined geometries including vertical thick dyke like bodies, prismatic block like features, and near horizontal layer segments in the upper crust.

Comparison of 3D MT model with deep seismic sounding seismic section (Kaila et al., 1981, 1989; Sridhar et al., 2007) along the two profiles (Thuadara-Sindad and Mehmadabad-Billimora), located in this region bring out interesting features showing a good correlation and consistency. The conductive features derived from 3D model show a high degree of consistency with gravity as well as seismic sections. The xenolith evidence (Dessai et al., 2010) in the NSL region suggest for the presence of ultramafic bodies. As may be seen from the results of gravity and seismic studies, the occurrence of mafic-ultramafic intrusive bodies should be wide spread and their occurrence should be extending into other parts of the NSL zone. This is evidenced from the geophysical anomalies observed all along the NSL zone (Singh and Meissner, 1995; Verma and Banerjee, 1992; Patro et al., 2005; Abdul Azeez et al., 2013). A majority of these subsurface mafic

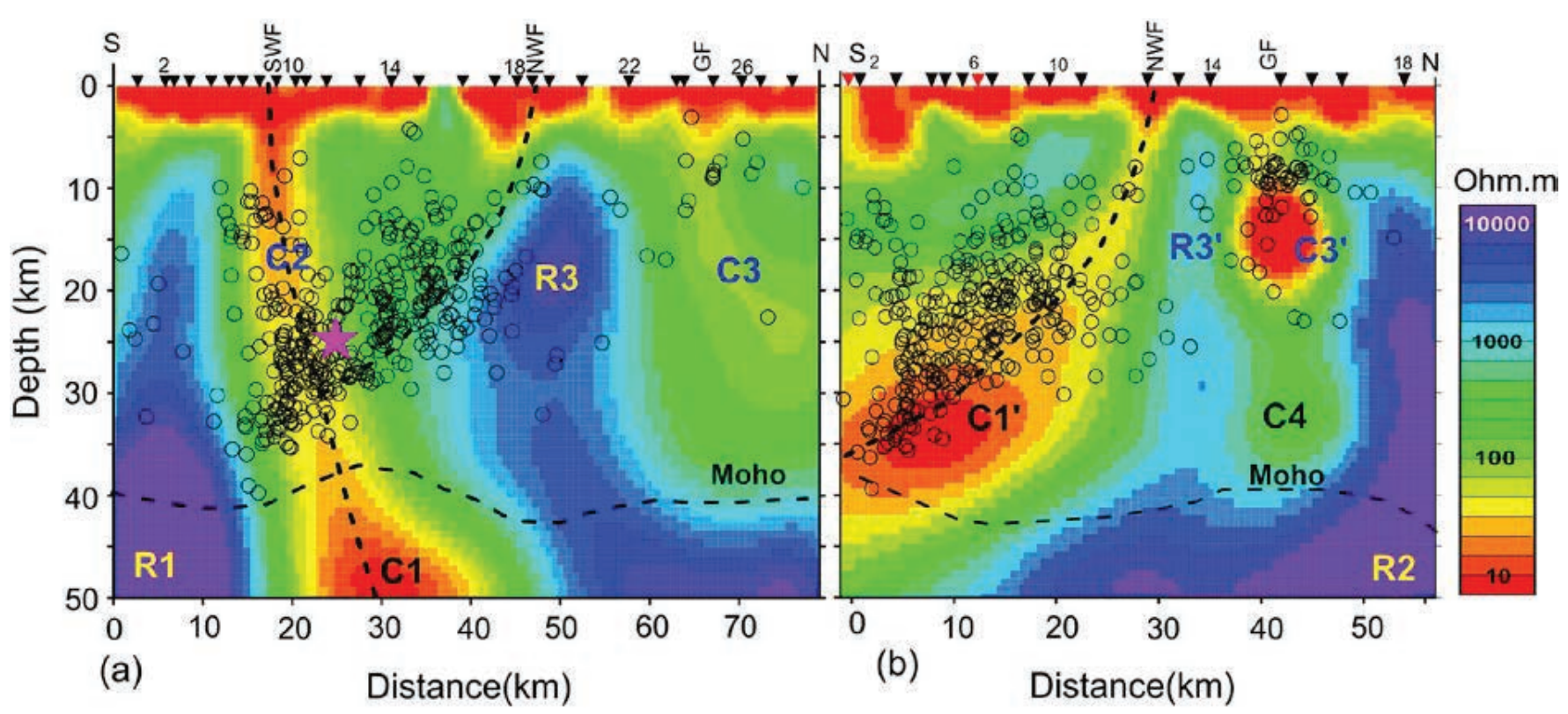

Figure 4. Two dimensional electrical image of the Kutch region (Kumar et al., 2017) along two NE-SW profiles ( see (4) in Figure 1 for the location). Top conductive layer represents Cenozoic and Mesozoic sediments. The seismicity $\left(M_{w}>=2.5\right)$ within $15 \mathrm{~km}$ of either side of the profile is plotted on to the model as open black circles. Pink star represents the 2001 Bhuj main shock. It may be seen that, the main shock is located at the junction of two fault traces. The Moho depths are taken from Chopra et al. (2010) and Rao et al. (2015). SWF: South Wagad Fault, NWF: North Wagad Fault, GF: Gedi Fault. 
bodies represented by conductive segments/bodies are inferred to have been emplaced during the Deccan volcanic episode which is known to be linked to the passage of the Indian continent over the Reunion hot spot (Morgan, 1981). The 3D MT model brings out several conductive bodies of different shapes and sizes (see 6 in Figure 1 for the location of study region). These linear conductors may be visualized as major pre-existing weak zones through which the upwelling magma has entered and moved upwards towards the upper crust. The weak zones have facilitated lateral spreading of magma as well as represented by horizontal conductive bodies (see Figure 5). Further, the deeper conductive blocks to which the linear conductive bodies are connected are inferred to correspond to magma chambers. It may thus be seen the geometry and configuration of these conductive bodies derived from the 3D MT model reflects closely the plumbing

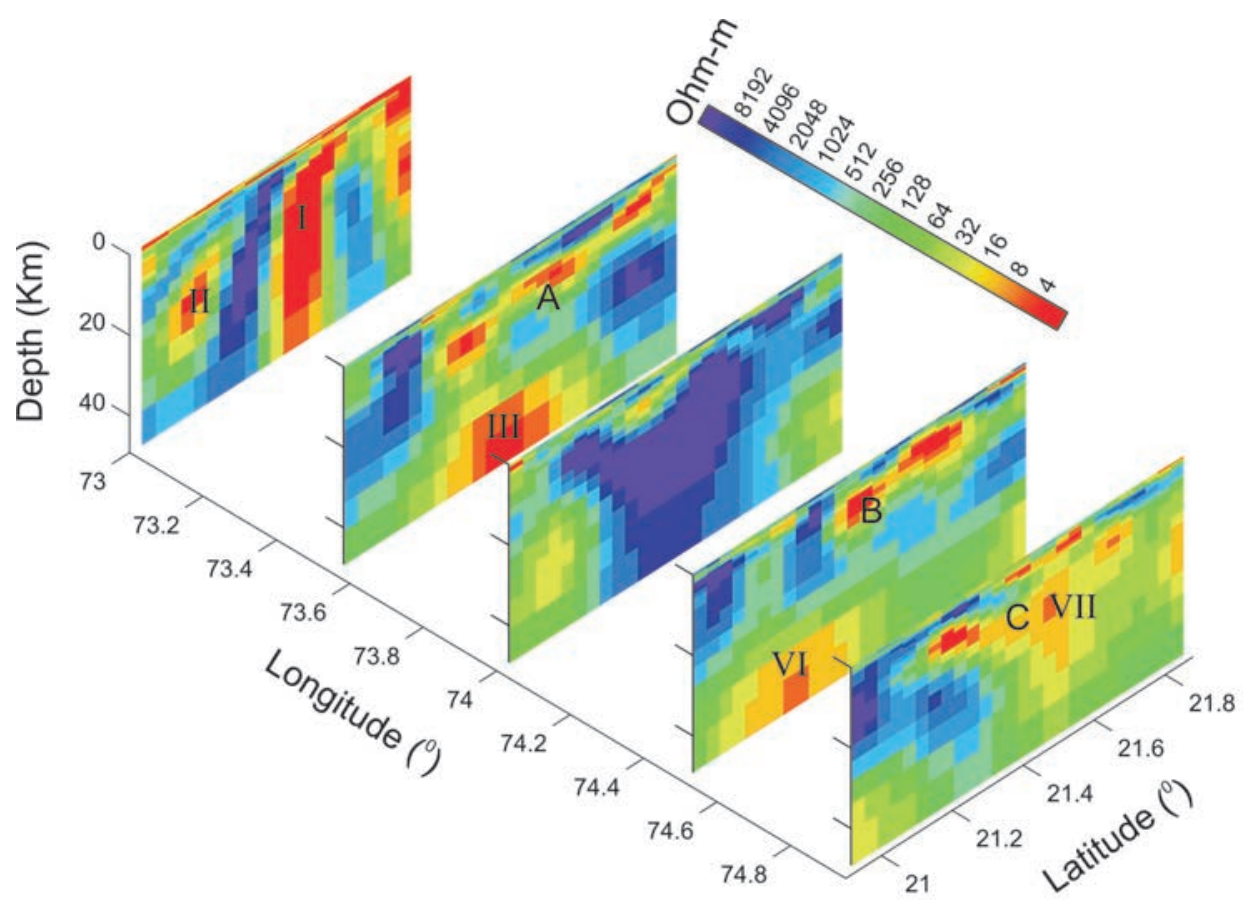

Figure 5. Deep geoelectric sections derived from the 3D inversion of the MT data in the Narmada son-Lineament region (Patro and Sarma, 2016).

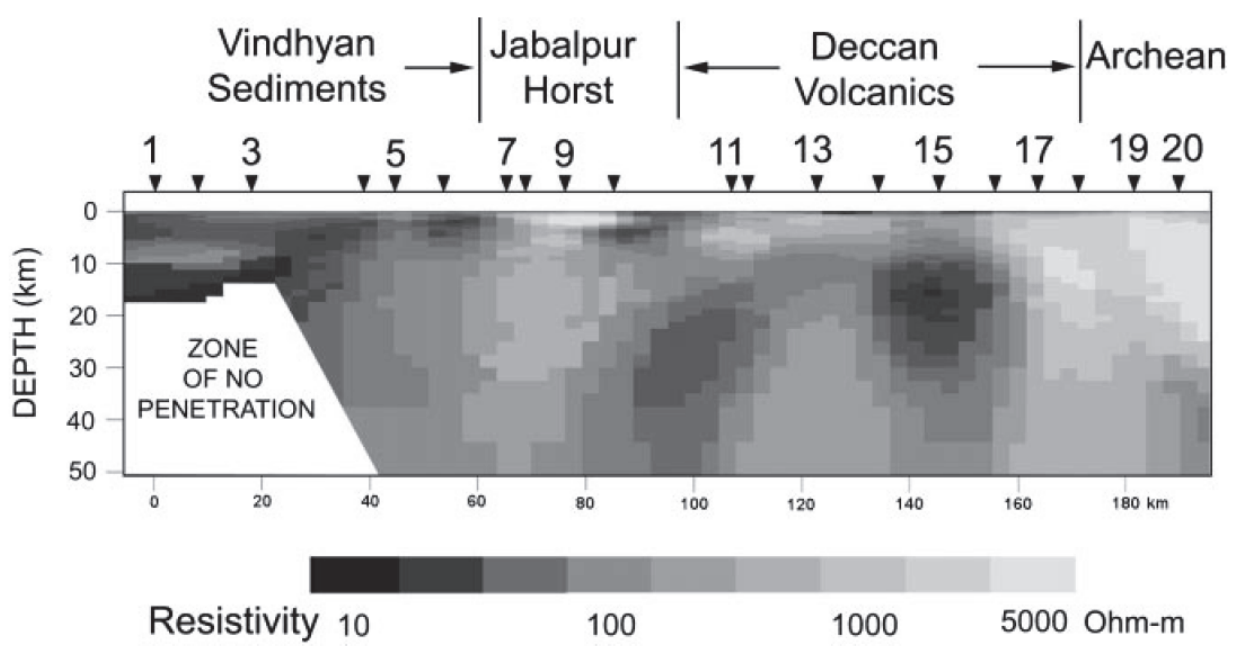

Figure 6. Geoelectric image of the NSL region along the profile from Mandla to Damoh (Gokarn et al., 2001; see 8 in Figure 1 for the location of the profile). geometry of the Deccan Volcanic Igneous Province (Patro and Sarma, 2016).

Further east, MT study was carried out across the Narmada SonLineament from Mandla to Damoh through Jabalpur (Gokarn et al., 2001). Two dimensional modelling of the MT data brought out the conductive nature of the crust (200 ohm-m) below Vindhyan basin (Figure 6). These findings suggest that the upper crust might have been eroded during the uplift and subsequent erosion process. Hence the present day basement of the Vindhyan basin might be the lower crust.

Magnetotelluric studies were carried out in the region to the north of NSL zone from Jabera to Jhansi traversing across the Bundelkhand craton (Gokarn et al., 2013). The results clearly brought out a high resistive block extending from shallow depths to deeper levels of as much as $60 \mathrm{~km}$. The high resistive block reflects the electrical signature of the Bundelkhand craton. Towards south, the 2D model (Figure 7) shows conductive regions which would correspond to the Vindhyan basin and Bijawars, that lie south of the craton. Further, the results also suggest the absence of any major tectonic activity in this region and the Bijawars seem to form the southern boundary of the Bundelkhand craton which is against the theory that the Bundelkhand region underwent subduction southward beneath the Dharwar craton.

\section{MT studies in the Eastern Indian Craton}

The Eastern part of the Indian shield is characterized by Archean neucleus of Singhbhum Granitie batholithic complex and ancient supra crustals referred to as Eastern Indian Craton (EIC). Broad band remote referenced MT studies were carried out over the southern segment of EIC to map the electrical conductivity structure of the crust and upper mantle (Bhattacharya and Shalivahan, 2002). The data were processed using hybrid robust i.e., combination of robust separately with coherency weighted and rho-variance. Moho depth of $46 \pm 2.6 \mathrm{~km}$ was derived from two dimensional modelling using Very Fast Simulated Annealing technique (Figure 8). While the Moho boundary is detected quite distinctly in seismological studies, in the case of electromagnetic studies including MT, in general, due to the presence of moderately conductive lower crust establishing this boundary has not been so successful. However, in the present case of EIC, due to the absence of such a 


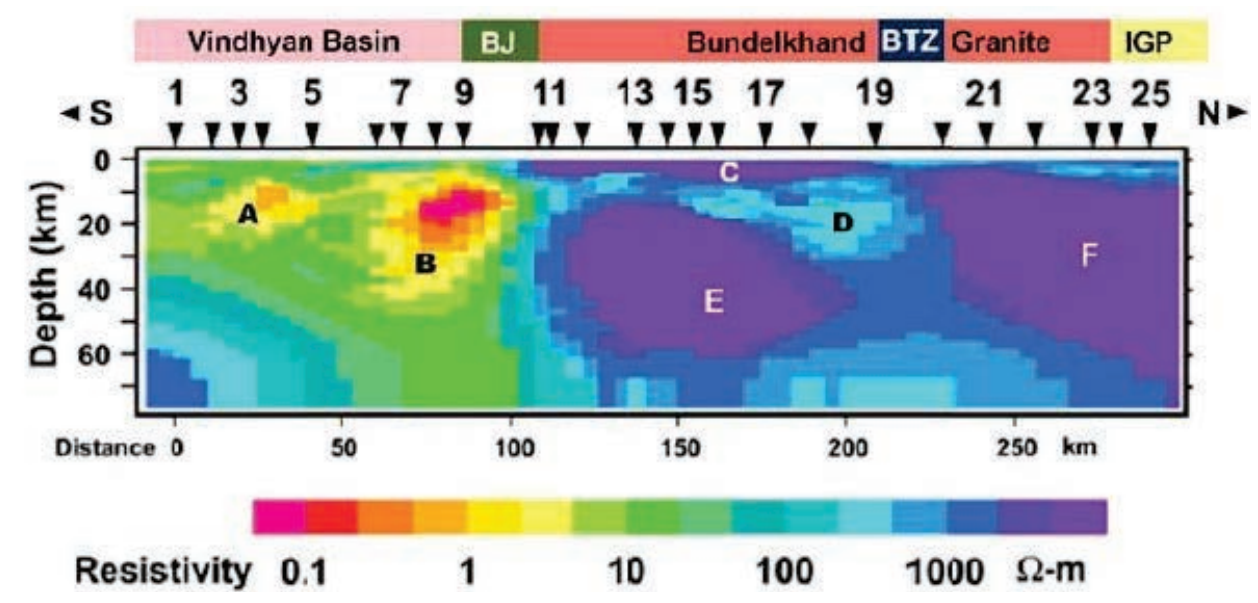

Figure 7. Two dimensional electrical image of Bundelkhand craton (Gokarn et al., 2013; see 7 in the Figure 1 for the location of the profile).

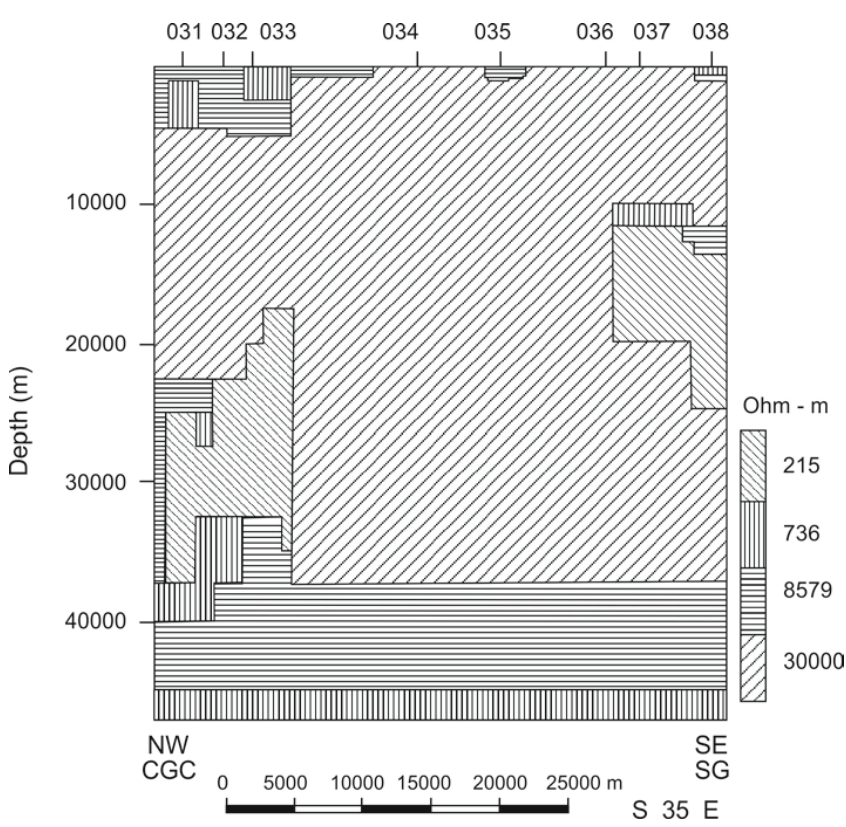

Figure 8. Electrical model over the Eastern Indian Craton (Bhattacharya and Shalivahan, 2002, see 9 in the Figure 1 for the location of the profile). CGC: Chottanagpur Gneisic Complex, SG: Singhbhum Granite.

conductive lower crust the electric Moho was delineated clearly. It might be due to the absence of overlying sedimentary material and underplating of mafic crust related to subduction process (Bhattacharya and Shalivahan, 2002).

\section{MT studies in Dharwar craton and Southern Granulite Terrain}

The Dharwar craton is the largest Archean craton of peninsular India. 2D modelling studies using MT and LMT data along a $250 \mathrm{~km}$ long profile (Figure 9) brought out the lithospheric electrical image below the Coorg and Western Dharwar Craton (Abdul Azeez et al., 2015). A vertical linear conductor (MC1) extending from Moho to deeper levels, has been identified between the Coorg block and the Western Dharwar Craton which is interpreted as paleo suture zone between two Archean terrains. Large upper mantle conductor (MC2) is delineated in the western segment of the western Dharwar craton suggesting modified cratonic lithosphere which is similar to the feature obtained in the Deccan Volcanic Province (Patro and Sarma, 2009).

The Southern Granulite Terrain (SGT) is one of the largest granulite terrains of the Earth exposing a wide range of deformed and retrograded hard crystalline rocks. It has a complex evolutionary history comprising of major tectonic events during the period from Archean to Proterozoic times. The SGT is divided broadly in to three blocks from north to south, viz. Salem, Madurai, and Trivandrum blocks. A large number of geophysical studies were carried out in the SGT during the last several decades primarily to investigate the crustal structure. Besides aiming at deciphering the crustal structure, the studies have also focussed on investigation of the major structural feature in this region, namely, the Palghat Cauvery shear zone (PCSZ). The PCSZ is believed to be a Late Neoproterozoic-Cambrian crustalscale suture zone and is considered to be a tectonic boundary between SGT and Dharwar craton. Based on geological observations, a plate tectonic model involving subduction-collision process was postulated to explain the amalgamation of Neoproterozoic SGT region with Dharwar craton with PCSZ as the suture zone (Santosh et al., 2009). Several geophysical studies were conducted over the craton and these include gravity (Subrahmanyam, 1978; Narain and Subrahmanyam, 1986; Mishra and Rao, 1993; Singh et al., 2003), seismic tomography (Rai et al., 1993, 2003), deep seismic sounding (Reddy et al., 2003), aeromagnetic (Reddi et al., 1988), and magnetotellurics (Harinarayana et al., 2003, 2006b; Naganjaneyulu and Harinarayana, 2003; Naganjaneyulu and Santosh, 2010; Naidu et al., 2011; Patro et al., 2014). The MT studies in particular carried out during the last three decades provided valuable insights into the crustal/upper mantle structures of the region. Two dimensional MT models of this region brought out a conductive feature in the PCSZ region, and was interpreted as fragments of the subducted oceanic crust, eclogitized and exhumed partly (Naganjaneyulu and Santosh, 2010). All the available MT data acquired until 2004 was used to derive a 3D electrical model of SGT (Patro et al., 2014). The MT data have been inverted on all the four impedances using Data Space Occam Inversion (Siripunvaraporn et al., 2005) which provided a realistic representation of the crustal as well as upper mantle electrical structure for the entire SGT. The crustal electrical structure as derived from the three dimensional MT modelling is characterized by a two-layered structure with a high resistive upper layer overlying a moderately resistive lower crustal layer. The upper high resistive layer is seen to be interspersed by three major linear conductive features. The crust penetrating conductive features mainly reflect, the manifestation of subduction/collision tectonics. Further, some of these linear conductive features which tend to extend to upper mantle depths, point out to large scale thick skin tectonic disturbances that the SGT witnessed. 
The 3D modelling results (see Figure 10) also brought a conductive feature that appears slightly to the south of PCSZ (C3) and this is a major feature mainly passing through the northern part of the Madurai block. This feature with a conductance of about 600 $\mathrm{S}$, extending from shallow to deeper levels $(\sim 50 \mathrm{~km})$ is inferred to be the electrical signature of subduction-collision zone in the SGT.
Another interesting feature that the 3D model brought out is a major north dipping conductor (C4) in the southern segment, reflecting the signature of the ACSZ that forms the boundary between the Madurai and Trivandrum blocks. Both the structural features corresponding to C3 and C4 must have played a significant role in the subductioncollision tectonic processes in the SGT region.

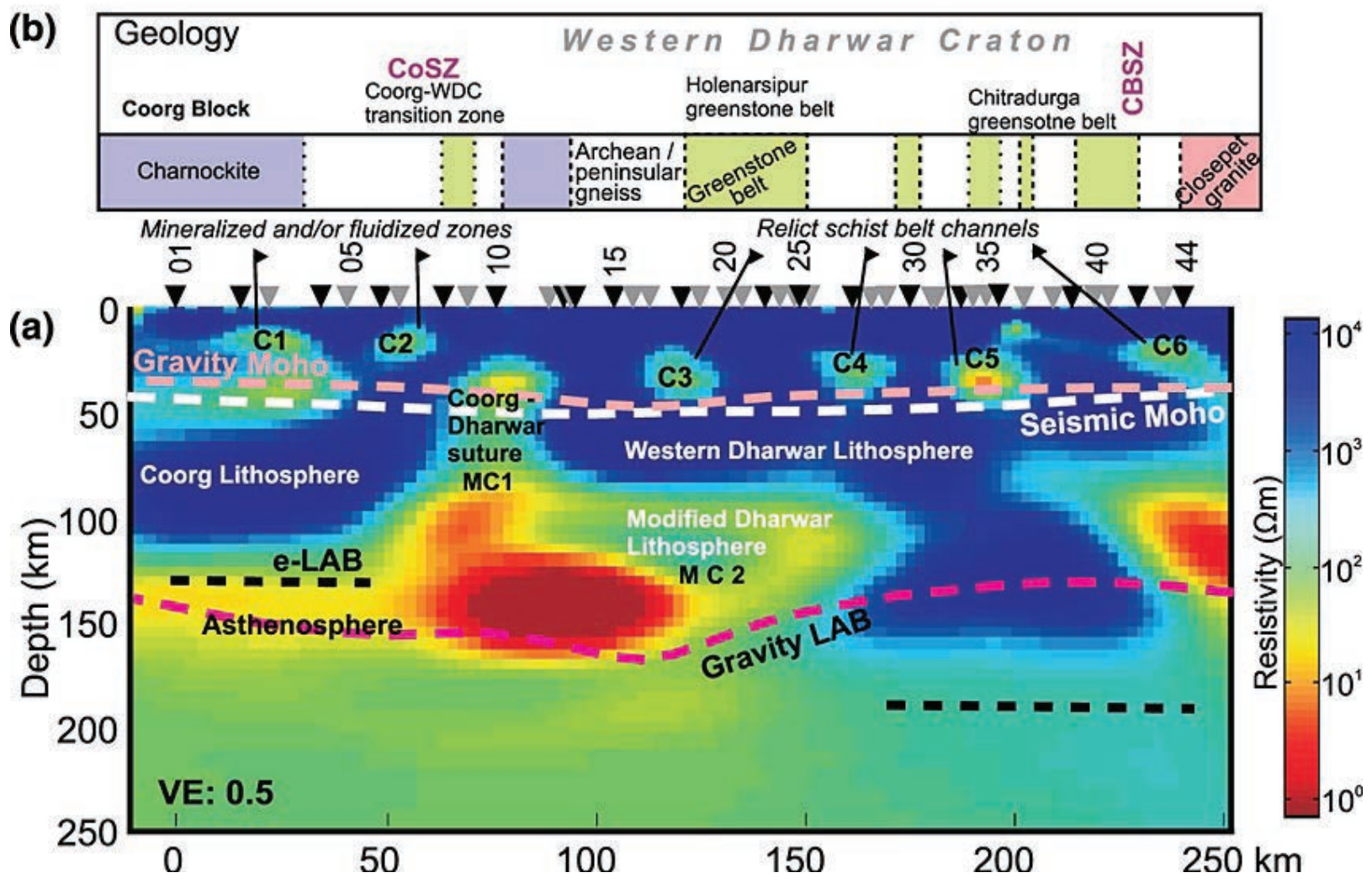

Figure 9. Two dimensional electrical image of the western segment of the Dharwar craton (Abdul Azeez et al., 2015; see 11 in the Figure 1 for the location of the profile).

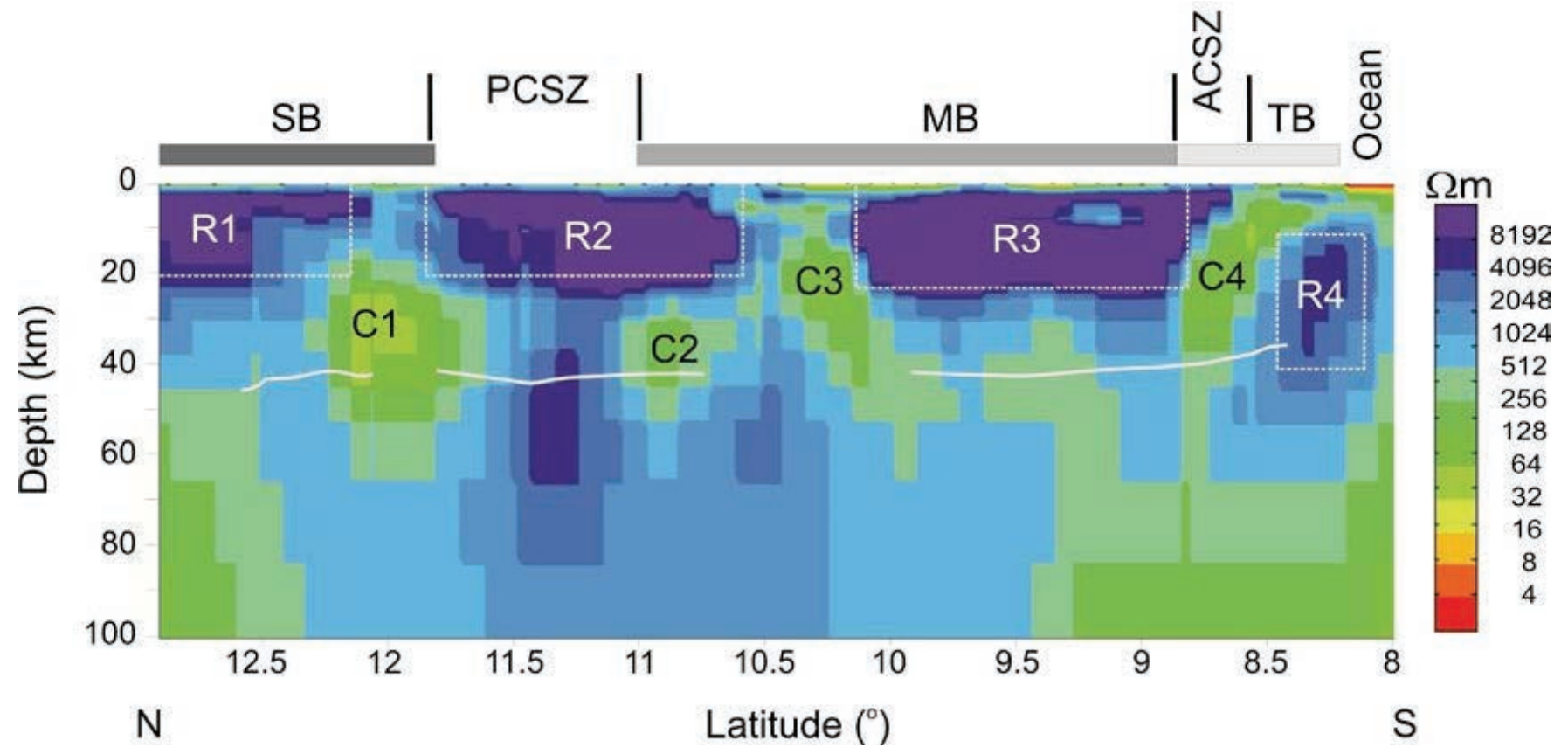

Figure 10. 3D electrical section from SGT region (Patro et al., 2014; see 12 in the Figure 1 for the location of the profile). SB: Salem Block, MB: Madurai Block, TB: Trivandrum Block 
Considering the deeper section (> $100 \mathrm{~km}$ ) corresponding to the upper mantle lithosphere both from geological and geochronological studies (Bhaskar Rao et al., 1996, 2008; Ghosh et al., 2004) suggest a distinct difference between the northern half (covering northern half of the Madurai block and PCSZ) and the southern half (the region comprising southern half of the Madurai block and Trivandrum block) of the SGT. The southern part of SGT shows high degree of intensity of deformation and metamorphism compared to the northern part (Santosh et al., 2006; Collins et al., 2010). It is interesting to note that the signatures of such high grade metamorphism and intense curst-mantle interaction extending to deeper level is also seen reflected in the electrical image derived from 3-D MT model (Patro and Sarma, 2014) in the form of relatively more conductive upper mantle lithospheric column in the southern half.

\section{MT studies in the Himalayan region}

The Himalayas are spectacular by product of Cenozoic collision between Indian and Asian continents and subsequent northward subduction of Indian continent (Powell and Conaghan, 1973; Hodges, 2000). The Indus Tsangpo suture zone (ITSZ) represents the approximate boundary between the Indian and Eurasian plates. The Himalayan fold thrust belt is located south of the ITSZ. From south to north the Himalayan tectonostratigraphy is divided into SubHimalayan, Lesser Himalayan, Greater Himalayan, and Tiebet Himalayan zones. Since magnetotelluric studies provide vital information about the presence or otherwise of fluids (melt or water) at the crustal and sub-crustal depths, which play significant role in changing the rheology of the crust and controls the style of deformation. Several MT studies were carried out in the Himalayan belt covering the regions from West to East. The first MT study in the Himalayas was carried out in the Northwestern Himalayas under HIMPROBE project. Results from analysis of broad band MT data (see 1 in Figure 1) show that the mid-crust is characterized by low resistivity (Gokarn et al., 2002). Arora et al. (2007), based on two dimensional modelling of LMT data (10-10,000s) collected along a traverse from Pang to Leh cutting across the ITSZ, suggest that the Indus suture is a northeast dipping low resistivity zone that merges with the low resistive mid-crustal layer. The low resistivity in the upper crustal section may be attributed to under thrusted sedimentary rocks (Thakur, 1981).

South of Indus suture the geoelectric structure is characterized by a northeast dipping low resistivity zone ( $30 \mathrm{ohm}-\mathrm{m})$. The depth of the Main Himalayan Thrust (MHT), which corresponds to the top of the Indian plate is derived from uniform crustal thickness. Reduced magmatism and slower convergence may facilitate direct under thrusting of sediments. These sedimentary rocks produce the low resistivity. However, to the north of Indus suture zone, the low resistivity may indicate the presence of fluids, either partial melt, aqueous fluids or a combination (Unsworth et al., 2005). The Indian lithosphere is characterised by high electrical resistivity due to the composition of crystalline rocks. The Indian lithosphere extends to the north of the Indus suture. In general, the MT data below a conductor has less resolution. As the conductance of the mid-crustal conductor is around $3000 \mathrm{~S}$, hence it was possible to image the lower crust beneath the crustal conductor.

MT studies were also carried out in the Garhwal Himalayas along a traverse (see 2 in Figure 1) passing across the major Himalayan thrusts (Israil et al., 2008). The two dimensional model (Figure 11) brought out a conductive layer in the south which is interpreted as the loose sediments that are transported from Higher Himalayan region. Another interesting feature obtained below MCT is a low resistive zone at mid-crustal depths. This conductive zone extends from the Lesser to Higher Himalayan region. High heat flow in this region coupled with presence of mid crustal conductive layer prompted Israil et al. (2008) to interpret this layer as partial melt. Rawat et al. (2014) presented a resistivity image across the Garhwal Himalaya and showed an intra-crustal high conducting layer (IC-HCL). A coincident receiver function study mapped a Low Velocity Layer (LVL) coinciding with the IC-HCL (Caldwell et al., 2013). Rawat et al. (2014) interpreted the HCL and LVL are due to the upward migration of metamorphic fluids. Further, Arora et al. (2017) discussed the role of fluids in the seismogenesis of Gorkha earthquake based on the HCL and LVL immediately above the plane of detachment.

Magnetotelluric studies were also carried out in the Sikkim Himalayas (see 3 in Figure 1) covering the eastern segment of Himalayan belt (Patro and Harinarayana, 2009; Kumar et al., 2014). In this segment, while the MBT follows an EW trend but the surface expression of the Main Central Thrust (MCT) takes a sinusoidal shape. In this segment, the Main Frontal Thrust (MFT) and Main Boundary Thrust (MBT) are positioned closely. The MFT, MBT and MCT tend to join to MHT at depth. Magnetotelluric studies were carried out in this region to derive the conductivity distribution within the collision regime. Two dimensional modelling of MT data carried out in the Sikkim Himalayan region brought out a conductive zone (10-40 ohmm) representing Siwalik sediments beneath MFT and MBT, which extends down up to upper crustal depths $(\sim 10 \mathrm{~km})$. The north east dipping conductive zone obtained along the profile is interpreted to represent MHT. The crustal column on the Indian side is modelled as a resistive segment (see Figure 11). In the higher Himalayas (i.e north of MCT) a conductive zone is identified which could be the electrical signature of the MHT (Patro and Harinarayana, 2009). The conductive nature of the MHT in higher Himalayas is suggested to be due to presence of metamorphic fluids released during dehydration reaction. Kumar et al. (2014) in their composite model, show that the region north of MCT is characterized by a highly complex structure with a mixture of conductive and resistive layers. This could be also due to the composite modelling approach followed by Kumar et al. (2014).

\section{Concluding remarks}

Magnetotelluric studies have been carried out over different litho units of India to provide the deep crustal/lithospheric structure in terms of electrical conductivity distribution. Deep electrical image has been provided by MT and LMT studies by several researchers in India covering North to South and West to East of India. We have developed a mobile application based on Android operating system for the geoscience researchers in India (Reddy et al., 2019). MT_App (Magnetotelluric) will be available for download from Google Play store soon. It gives the information about the published MT models and the sounding curves over different geological terrains of India. MT studies in the Himalayan region where active tectonics is going on helped understanding the geometry of MFT and the MCT. The ITSZ is characterized by low resistive zone dipping in the NE direction. All the MT and LMT studies carried out in the Himalayan region brought out the depth to the top of Indian plate. The MCT zone in the Garhwal and Sikkim Himalayas are characterized by lowresistive zone. These zones are interpreted differently; in the Garhwal 

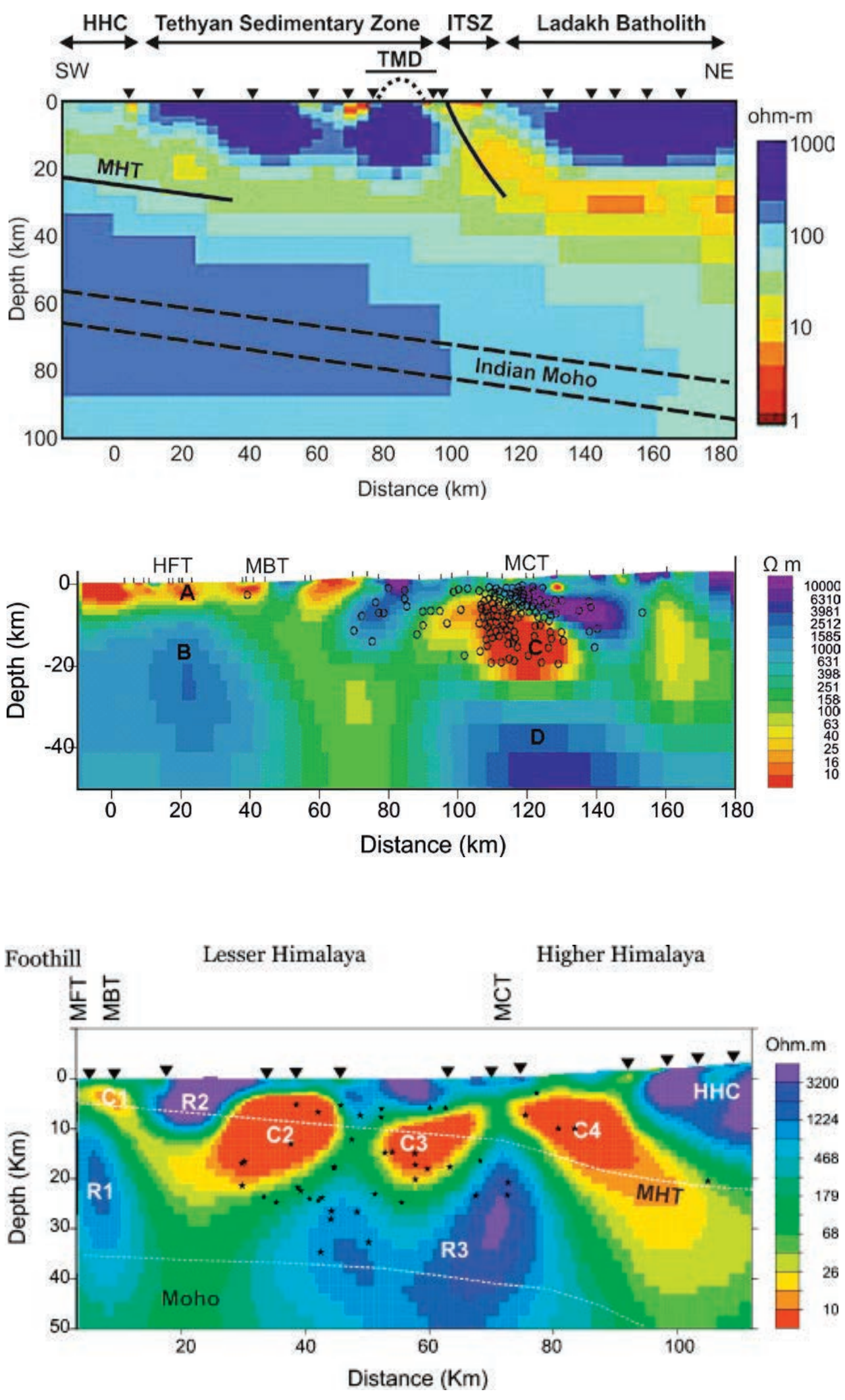

Figure 11. Two dimensional electrical image at three transacts along Himalayan region. Top: Across the ITSZ in the NW Himalaya (Arora et al., 2007) Middle: in the Garhwal Himalaya across the MCT (Israil et al., 2008). Local seismicity is plotted as unfilled black circles Bottom: in the Sikkim Himalayas across the MCT (Patro and Harinarayana, 2009). The location of Indian Moho is taken from the gravity studies (Tiwari et al., 2006). Filled black stars represent the earthquake locations. HHC, High Himalayan Crystalline; TMD, Tso Morari Dome; ITSZ, Indus Tsangpo Suture Zone. See 1, 2, 3 in Figure 1 for the location of the profiles.
Himalayas they are attributed to the partial melts where as in the Sikkim Himalayas it is inferred to represent the metamorphic fluids that are released due to dehydration reactions.

The Deccan Volcanic Province has been shown to be a highly favourable geological terrain for MT application mainly due to the contrasting resistivity values between the top Deccan traps and underlying granitic basement and or sediments. The deep electrical images of the region have brought out several hidden faults beneath the Deccan trap cover and mapped the pathways for the Deccan Volcanism in the areas of Narmada-Son Lineament zone. An upper mantle crustal conductor delineated in the DVP region could be related to the postulated subduction of western Dharwar craton underneath the Eastern Dharwar craton. In the Kutch region, the MT studies together with seismological studies brought out the fluid filled channel that connects the upper mantle to the South Wagad Fault. A significant result from the MT studies in the East Indian Craton is the identification of the electric moho at a depth of $46 \pm 2.6 \mathrm{~km}$.

A subduction-collision zone is identified from the 3D modelling studies of the MT data in SGT region, south of PCSZ characterizing a feature with a conductance of about 600 S. MT studies clearly indicate that the upper mantle lithosphere of the SGT shows a distinct difference between the north and southern segments. The hypothesis of high degree of deformation and metamorphism in the southern part of SGT as compared to the northern part is brought out clearly in the electrical image derived from the 3D modelling studies.

Of late a number of grid pattern MT studies have been carried out over the Indian continent. Three dimensional modelling of these data sets and integrating the MT modelling results with seismological and gravity data is the way forward to derive a well acceptable and geologically meaningful model of different structural scenarios and litho units of Indian continent. 


\section{Acknowledgements}

I would like to thank Dr. V. M. Tiwari, Director, CSIR-NGRI for inviting me to write this paper for 36th IGC Legacy Volume. Heartfelt thanks to Dr. S. V. S. Sarma for many fruitful discussions. The research was carried out under the financial support from MLP-6404-28 (BPK). I am thankful to both the reviewers and the editor Dr. V. M. Tiwari for their constructive suggestions, which have improved the clarity in the manuscript.

\section{References}

Abdul Azeez, K.K., Unsworth, M.J., Patro, P.K., Harinaryana, T., Sastry, R.S., 2013 Resistivity structure of the Central Indian Tectonic Zone (CITZ) from multiple magnetotelluric (MT) profiles and tectonic implications. Pure Appl. Geophys. 170, 2231-2256.

Abdul Azeez, K.K., Veeraswamy, K., Gupta, A. K., Babu, N., Chandrapuri, S., Harinarayana, T., 2015 The electrical resistivity structure of lithosphere across the Dharwar craton nucleus and Coorg block of South Indian shield: Evidence of collision and modified and preserved lithosphere, J. Geophys. Res. Solid Earth,120, 6698-6721, doi:10.1002/2014JB011854.

Arora, B.R., Unsworth, M.J. and Rawat, G., 2007 Deep resistivity structure of the northwest Indian Himalaya and its tectonic implications, Geophysical Research Letters, 34, L04307.

Arora, B.R., Bansal, B.K., Prajapati S.K. Sutur, A.K. \& Nayak, S., 2017 Seismotectonics and Seismogenesis of Mw7.8 Gorkha Earthquake and its Aftershocks. Journal of Asian Earth Sciences, 133, 2-11, http://dx.doi.org/10.1016/j.jseaes.2016.07.018

Artemieva, I.M., 2006 Global $1^{\circ} \times 1^{\circ}$ thermal model TC1 for the continental lithosphere: Implications for lithosphere secular evolution, Tectonophysics, 416, 245-277.

Bhaskar Rao, Y.J., Chetty, T.R.K., Janardhan, A.S., and Gopalan, K., 1996 Sm-Nd and Rb-Sr ages and P-T history of the Archean Sittampundi and Bhavani layered meta-anorthosite complexes in Cauvery shear zone, South India, evidence for eoproterozoic reworking of Archean crust, Contrib. Mineral. Petrol., 125, 237250.

Bhaskar Rao, Y.J., Vijaya Kumar, T., Krishna, K.V.S.S., and, Tomson, J.K., 2008 The emerging pattern of crust-formation and recycling history in the Precambrian Dharwar Craton and the Southern Granulite Terrain, Southern India, constraints from recent geochronological

and isotopic results, Mem. Geol. Soc. India., 74, 147-168.

Bhattacharya, B.B., and Shalivahan, 2002 The electric moho underneath Eastern Indian Craton, Geophysical Research Letters, 29, 10, 1376, 10.1029/2001GL014062.

Bhattacharya B. B., Sinharay R. K., Srivastava S. V., 2003 MT survey over the geothermal region of Bakreshwar for investigation deeper geo-electrical structure. J Geophys 24(1):41-44.

Caldwell, W. B., Klemperer, S. L., Lawrence, J. F., Rai, S. S., Ashish, 2013 Characterizing the Main Himalayan Thrust in the Garhwal Himalaya, India with receiver function CCP stacking, Earth Planet. Sci. Lett. 367, 15-27.

Chopra, S., Rao, K.M., and Rastogi, B.K., 2010 Estimation of sedimentary thickness in Kachchh Basin, Gujarat using SP converted phase, Pure Appl. Geophys., 167, 1247-1257.

Chopra, S., Chang, T. M., Saikia, S., Yadav, R. B. S., Choudhury, P. Roy, K. S., 2014, Crustal structure of the Gujarat region, India: new constraints from the analysis of teleseismic receiver functions, J. Asian Earth Sci., 96, 237-254.
Collins, A. S., Clark, C., Chetty, T.R.K., and Santosh, M., 2010 Ediacaran-Cambrian tectonic evolution of southern India, Indian J. Geol., 80, 23-40.

Dessai, A.G., Peinado, M., Gokarn, S.G., and Downes, H., 2010 Structure of the deep crust beneath the Central Indian tectonic zone: an integration of geophysical and xenolith data. Gondwana Res.17, 162-170.

Ghosh, J.G., de Wit, M.J., and Zartman, R.E., 2004 Age and tectonic evolution of Neoproterozoic ductile shear zones in the Southern Granulite Terrain of India, with implications for Gondwana studies, Tectonics, 23, TC3006, doi:10.1029/2002TC001444.

Gokarn, S.G., Rao, C.K., Gupta, G., Singh, B.P., Yamashita, M., 2001 Deep crustal struc-ture in central India using magnetotelluric studies. Geophys. J. Int.144, 685-694.

Gokarn, S.G., Gupta, G., Rao, C.K., and Selvaraj, C., 2002 Electrical structure across the Indus Tsangpo suture and Shyok suture zones in NW Himalaya using magnetotelluric studies, Geophys. Res. Lett., 29(8), 1251, doi:10.1029/2001GL014325.

Gokarn, S.G., Rao, C.K., Selvaraj, C., Gupta, G. and Singh, B.P., 2013 Crustal evolution of the Archean Bundelkhand Craton, Central India, Journal of Geological Society of India, 82, pp.455460.

GSI, 1998 Geological map of India, Scale 1:2000000, Geological Survey of India, India.

Gupta, H. K., Sarma, S. V. S., Harinarayana, T. and Virupakshi, G., 1996 Fluids below the hypocentral region of the Latur earthquake: India: Geophysical Indicators. Geophysical Research Letters, v.23, 1569-1572.

Harinarayana, T., Naganjaneyulu, K., Manoj, C., Patro, B.P.K., Begam, S.K., Murthy, D.N., Rao, M., Kumaraswamy, V.T.C., and Virupakshi, G., 2003 Magnetotelluric investigations along Kuppam Palani geotransect, south India, 2D modeling results, Mem. Geol. Soc. India, 50, 107-124.

Harinarayana T., Abdul Azeez K. K., Murthy D. N., Veeraswamy K., Rao S. P. E., Manoj C., Naganjaneyulu K., 2006a Exploration of geothermal structure in Puga geothermal field, Ladakh Himalayas, India by magnetotelluric studies. J Appl Geophys 58:280-295.

Harinarayana, T., Naganjaneyulu, K., and Patro, B.P.K., 2006b Detection of a collision zone in south India shield region from magnetotelluric studies, Gondwana Res., 10, 48-56.

Harinarayana, T., 2008 Application of magnetotelluric studies in India, Mem. Geol. Soc. of India, 68, 337-356.

Hodges, K.V., 2000 Tectonics of the Himalaya and southern Tibet from two prospective, Geological Society American Bulletin, 112, 324-350.

Hofmann, C., Feraud, G., and Courtillot, V., $2000{ }^{40} \mathrm{Ar} /{ }^{39} \mathrm{Ar}$ dating of mineral separates and whole rocks from the Western Ghats lava pile: Further constrains on duration and age of the Deccan Traps, Earth Planet. Sci. Lett., 180, 13-28.

Irifune, T., and Ringwood, A.E., 1987 Phase transformations in primitive MORB and pyrolite compositions to 25Gpa and some geophysical implications, in High pressure research in mineral physics, Geophy. Monogr. Ser., Vol. 39 edited by M.H.Manghnani and Y. Syono, pp 231-242,AGU, Washington,D.C.

Israil, M., Tyagi, D.K., Gupta, P.K. and Niwas, S., 2008 Magnetotelluric investigations for imaging electrical structure of Garhwal Himalayan corridor, Uttarakhand, India, Journal of Earth System Science, 117, 3, 189-200.

Jones, A.G., Lezaeta, P., Ferguson, I.J., Chave, A.D., Evans, R.L., Garcia, X and Spratt, J., 2003 The electrical structure of the Slave craton, Lithos, 71, 505-527.

Jordan, T.H., 1979 Mineralogies, densities and seismic velocities of garnet lherolites and their geophysical implications, in The Mantle Sample: Inclusions in Kimberlites and Other Volcanics, pp. 1- 
14, Boyd, F.R. \& Meyer, H.D.A., eds, American Geophysical Union, Washington DC.

Kaila, K.L., Reddy, P.R., Dixit, M.M., and Lazrenko, M.A., 1981 Deep crustal structure at Koyna, Maharashtra indicated by Deep Seismic Soundings, J. Geol. Soc. India, 22, 1-16.

Kaila, K.L., Reddy, P.R., Dixit, M.M. and Rao, P.K., 1985 Crustal structure across the Narmada-Son lineament, Central India from deep seismic soundings, J. Geol. Soc. India, 26, pp. 465-480.

Kaila, K.L., 1988 Mapping the thickness of Deccan trap flows in India from DSS studies and inferences about a hidden Mesozoic basin in the Narmada-Tapti region, in Deccan flood basalts, edited by K. V. Subbarao, Mem. Geol. Soc. Ind., 10, 91- 116.

Kaila, K. L., Rao, I. B. P., Rao, P. K., Rao, N. M., Krishna, V. G., Sridhar, A. R., 1989, DSS studies over Deccan traps along the Thuadara-Sendhwa-Sindad profile, across Narmada-Son lineament, India, AGU Geophysical Monograph Series, 51, 113127.

Kumar, G.P., Manglik, A., and Thiagarajan, S., 2014 Crustal geoelectric structure of the Sikkim Himalaya and adjoining Gangetic foreland basin, Tectonophysics, 637, 238-250.

Kumar, G.P., Mahesh, P., Nagar, M., Mahender, E., Kumar, V., Mohan, K. and Kumar, M. R., 2017 Role of deep crustal fluids in the genesis of intraplate earthquakes in the Kachchh region, northwestern India, Geophysical Research Letters, 10.1002/ 2017 GL072936.

Kumar, P.V.V., Patro, P.K., Rao, P.B.V., Singh, A.K., Kumar, A., and Nagarjuna, D., 2018 Electrical resistivity cross-section across northern part of Saurashtra region: An insight to crystallized magma and fluids, Tectonophysics, 744, 205-214.

Mishra, D.C., and Rao, M.B.S.V., 1993 Thickening of crust under the granulite province of South India and associated tectonics based on gravity magnetic study, Mem. Geol. Soc. India, 25, 203219.

Mohan, G., and Kumar, M. R., 2004, Seismological constraints on the structure and composition of western Deccan volcanic province from converted phases, Geophys. Res. Lett., 31, L02601, doi:10.1029/2003GL018920.

Mohan, K., Pavan Kumar, G., Chaudhary, P., Choudhary, V. K., Nagar, M., Khuswaha, D., Patel, P., Gandhi, D., Rastogi, B. K., 2017 Magnetotelluric investigations to identify geothermal source zone near Chabsar hotwater spring site, Ahmedabad, Gujarat, Northwest India, Geothermics, 65, 198-209.

Morgan, W.J., 1981 Hotspot tracks and the opening of the Atlantic and Indian Oceans. In: Emiliani, C. (Ed.), The Sea, vol. 7. John Wiley, New York, pp. 443-487.

Naganjaneyulu, K., and Harinarayana, T., 2003 Evidence for continent-continent collision zone in the South Indian Shield region, Gondwana Res., 6, 902-911.

Naganjaneyulu, K., Santosh, M., 2010 The Central India tectonic zone: a geophysi-cal perspective on continental amalgamation along a Mesoproterozoic suture. Gondwana Res. 18, 547-564.

Naidu, G.D., Manoj, C., Patro, P.K., Sreedhar, S.V., and Harinarayana, T., 2011 Deep electrical signatures across the Achankovil shear zone, Southern Granulite Terrain inferred from magnetotellurics, Gondwana Res., 20, 405-426.

Narain, H., and Subrahmanyam, C., 1986 Precambrian tectonics of the southern Indian shield inferred from geophysical data, J. Geol., 94, 187-198.

Negi, J. G., Pandey, O. P. and Agarwal, P. K., 1986, Super mobility of hot Indian lithosphere, Tectonophysics, 131, 147- 156, doi:10.1016/0040 1951(86)90272 6.

Olsen, P.E., 1999 Giant Lava Flows, Mass Extinctions, and Mantle Plumes, Science 284 (5414), 604. DOI: 10.1126/science.284. 5414.604.
Pande, K., Pattanayak, S.K., Subbarao, K.V., Navaneethakrishnan, P., and Venkatesan, T.R., $2004{ }^{40} \mathrm{Ar}-{ }^{39} \mathrm{Ar}$ age of a lava flow from the Bhimashankar formation, Giravali Ghat, Deccan Traps, Proc. Indian Acad. Sci, 113, 755-758.

Pandey D., Singh S., Sinha M., MacGregor L., 2009 Structural imaging of Mesozoic sediments of Kachchh, India and their hydrocarbon prospects. Mar Pet Geol 26:1043-1050.

Patro, P.K., and Harinarayana, T., 2009 Deep geoelectric structure of the Sikkim Himalayas (NE India) using magnetotelluric studies. Phys Earth Planet 173:171-176.

Patro, P.K. and Sarma, S.V.S., 2009 Lithospheric electrical imaging of the Deccan trap covered region of western India. Jour. Geophys. Res., v.114, B01102.

Patro, B.P.K., Brasse, H., Sarma, S.V.S., and Harinarayana, T., 2005 Electrical structure of the crust below the Deccan Flood Basalts (India), inferred from magnetotelluric soundings, Geophy. J. Int., 163, 931-943, 2005.

Patro, P.K., Sarma, S.V.S., and Naganjaneyulu, K., 2014 Threedimensional lithospheric electrical structure of Southern Granulite Terrain, India and its tectonic implications, Journal of Geophysical Research, v. 119, 71-82, doi:10.1002/2013JB010430, 2014

Patro P. K., Abdul Azeez K. K., Veeraswamy K., Sarma S. V. S., Sen M. K., 2015 Sub-basalt sediment imaging-the efficacy of magnetotellurics. J Appl Geophys 121:106-115. doi:10.1016/ j.jappgeo.2015.07.010.

Patro, P.K., Sarma, S.V.S., 2016 Evidence for an extensive intrusive component of the Deccan Large Igneous Province in the Narmada Son Lineament region, India from three dimensional magnetotelluric studies. Earth Planet. Sci. Lett. 451, 168-176.

Patro, P. K., 2017 Magnetotelluric Studies for Hydrocarbon and Geothermal Resources: Examples from the Asian Region. Surveys in Geophysics, 38(5), 1005-1041, DOI 10.1007/s10712-0179439-x.

Powell and Conaghan, 1973 Plate tectonics and the Himalayas, Earth and Planetary Science Letters, 20 (1), 1-12.

Rai, S.S., Srinagesh, D., and Gaur, V.K., 1993 Granulite evolution in South India-A seismic tomographic perspective, Mem. Geol. Soc. India, 25, 235-263.

Rai, S.S., Priestley, K., Suryaprakasam, K., Srinagesh, D., Gaur, V.K., and Du, Z., 2003 Crustal shear velocity structure of the South Indian Shield, J. Geophys. Res., 108(B2), 2088, doi:10.1029/ 2002JB001776.

Rao, C.K., Ogawa, Y., Gokarn, S.G., and Gupta, G., 2004 Electromagnetic imaging of magma across the Narmada Son lineament, central India. Earth Planets Space 56 (2), 229-238.

Rao, K. M., Kumar, M. R., and Rastogi, B. K., 2015 Crust beneath the northwestern Deccan Volcanic Province, India: Evidence for uplift and magmatic underplating, J. Geophy. Res., 120, 33853405, doi:10.1002/2014JB011819.

Reddy, K. C., Patro, P. K. and Krishna, M. S., 2019 Android application for the dissemination of magnetotelluric research work in India (MT_App), The Journal of Indian Geophysical Union, 23, 6, 521-532.

Shanker, R., 1991 Thermal and crustal structure of SONATA, a zone of mid continental rifting in Indian Shield, J. Geol. Soc. India, 37, 211-220

Tiwari, V. M., Vyghreswara Rao, M.B.S., Misra, D.C., Singh B., 2006 Crustal structure across Sikkim, NE Himalay from new gravity and magnetic data Earth Planet. Sci. Lett., 247, 61-69

Rawat, G., Arora, B. R. \& Gupta, P. K., 2014 Electrical resistivity cross-section across the Garhwal Himalaya: Proxy to fluidseismicity linkage. Tectonophysics, 637, 68-79.

Reddi, A.G.B., Mathew, M.P., Singh, B., and Naidu, P.S., 1988 Aeromagnetic evidence of crustal structure in the granulite terrain 
of Tamil Nadu-Kerala, J. Geol. SOC. India, 32, 368-381.

Reddy, P.R., Rajendra Prasad, B., Vijaya Rao, V., Sain, K., Prasad Rao, P., Khare, P. and Reddy, M. S., 2003 Deep seismic reflection and refraction/wide angle reflection studies along Kuppam-Palani transect in the Southern Granulite Terrain of India, Mem. Geol. Soc. India, 50, 78-106.

Santosh, M., Collins, A.S., Tamashiro, I., Koshimoto, S., Tsutsumi, Y., and Yokoyama, K., 2006 The timing of ultrahigh-temperature metamorphism in Southern India: U-Th-Pb electron microprobe ages from zircon and monazite in sapphirine-bearing granulites, Gondwana Res., 10(1-2), 128-155.

Santosh, M., Maruyama, S., and Sato, K., 2009 Anatomy of a Cambrian suture in Gondwana: Pacific-type orogeny in southern India?, Gondwana Res., 16, 321-341.

Sarma S. V. S., Harinarayana T., Gupta M. L., Sarma S. R., Kumar R., Sanker Narayan P. V., 1983 A reconnaissance telluric survey in northern parts of Konkan geothermal province, India. Geophys Res Bull 21(1):91-99.

Sarma, S.V.S., Patro, B.P.K., Harinarayana, T., Veeraswamy, K., Sastry, R.S., and Sarma, M. V.C., 2004 A magnetotelluric (MT) study across the Koyna seismic zone, Western India: evidence for block structure, Phys. Earth Planet. Inter., 142/1-2, 23-36.

Sastry, R. S., Nagarajan, N and Sarma, S. V. S. 2007 Electrical imaging of deep crustal features of Kutch, India, Geophysical Journal International, 172, 934-944.

Satpal Singh O. P., Sar D., Chatterjee S. M., Sawa S., 2006 Integrated interpretation for sub-basalt imaging in Saurashtra Basin, India. Lead Edge 25:882-885.

Singh, A.P., Meissner, R., 1995 Crustal configuration of the NarmadaTapti region (India) from gravity studies. J. Geodyn. 20, 111127.

Singh, A.P., Mishra, D.C., Vijaya Kumar, V., and Rao, M.B.S.V.,
2003 Gravity magnetic signatures and crustal architecture along Kuppan Palani geotransect, South India, Mem. Geol. Soc. India, 50, 139-163.

Sinharay R. K., Srivastava S., Bhattacharya B. B., 2010 Audiomagnetotelluric studies to trace the hydrological system of thermal fluid flow of Bakreswar Hot Spring, Eastern India: a case history. Geophysics 75(5):B187-B195.

Sircar A., Shah M., Sahajpal S., Vaidya D., Dhale S., Chaudhary A., 2015 Geothermal exploration in Gujarat: case study from Dholera. Geotherm Energy 3:22

Siripunvaraporn, W., Egbert, G., Lenbury, Y., and Uyeshima, M., 2005 Three-dimensional magnetotelluric inversion: Data-space method, Phys. Earth Planet. Inter., 150, 3-14.

Sridhar, A.R., Tewari, H.C., Vijara Rao, V., Satyavani, N., Thakur, N.K., 2007 Crustal velocity structure of the Narmada-Son lineament along the Thuadara-Sendhwa- Sindad profile in the NW part of Central India and its geodynamic implications. J. Geol. Soc. India 69, 1147-1160.

Subrahmanyam, C., 1978 On the relation of gravity anomalies to geotectonics of the Precambrian terrains of the South Indian Shield, J. Geol. Soc. India, 19, 251-263.

Thakur, V. C., 1981 Regional framework and geodynamic evolution of the Indus Tsangpo suture zone in the Ladakh Himalaya, Trans. R. Soc. Edin-burgh Earth Sci., 72, 89 - 97.

Unsworth, M. J., A. G. Jones, W. Wei, G. Marquis, S. G. Gokarn, J. E. Spratt, and the INDEPTH MT Team, 2005 Crustal rheology of the Himalaya and southern Tibet inferred from magnetotelluric data, Nature, 438, $78-81$.

Verma, R.K., Banerjee, P., 1992 Nature of continental crust along the Narmada-Son lineament inferred from gravity and deep seismic sounding data. Tectono-physics 202, 375-397.

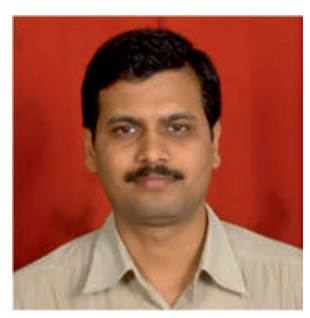

Prasanta K. Patro is a Senior Principal Scientist and Activity Incharge in Magnetotelluric division of CSIR-National Geophysical Research Institute, Hyderabad, India. His main research area includes application of magnetotellurics in solid Earth geophysics and for resource exploration. He is the recipients of post-doctoral fellowship from the Oregon State University, USA; Japan Science Promotion Society (JSPS) and the BOYSCAST fellowship from Government of India. 